\title{
Improving Irrigation Water Management in Delta of Egypt
}

\author{
Walaa Y. Elnashar \\ Water Engineering and Water Structure Engineering Department, Faculty of Engineering, Zagazig University
}

\begin{abstract}
Water management is an important element of irrigated crop production. This study is carried out in two stages. In the first stage, performance of irrigation water management is assessed using two models for irrigation schedule by calculating eapo-transpiration and studying the effect of relative evapo-transpiration on relative yield of crop and the effect of depth of water irrigation on the net revenue, and in the second stage the effect of saline water in crop production is studied by mixing supply of saline drainage water, moderately sewage water, and fresh water in six ratios applied on crops yield which cultivated in Delta of Egypt. Moreover yield is high in alternate practice only with fresh water, whereas moderate saline irrigation waters in mixed practice gave the highest values of yield and growth. There is a strong negative relationship between crop yield and seasonal average of electrical conductivity of the soil solution.
\end{abstract}

Keywords: Irrigation scheduling; Irrigation system evaluation; Irrigation water management; Saline and fresh water.

\section{Introduction}

Irrigation water management is the act of timing and regulating irrigation water application in a way that will satisfy the water requirement of the crop without wasting water, soil, and plant nutrients and degrading the soil resource, and the effect of saline water in crop yield, thus there are many researches in this branch such as Burton, Kivumbi, and El-Askari [1] identified priority areas of research to improve irrigation water management in developing countries. Leenhardt, Trouvat, Gonzalès, Pérarnaud, Prats, and Bergez [2] collected database to respect the operational constraints of the water manager, namely early delivery and cheap acquisition. Leenhardt, Trouvat, Gonzalès, Pérarnaud, Prats, and Bergez [3] presented the water management of the Neste system: the area, the current procedure of management and the current decision support system in use. Ortega, Juan, and Tarjuelo [4] presented the main methodological aspects and results obtained from the activity of the Irrigation Advisory Service for Farmers of Castilla-La Mancha, Spain. Abdel Gawad, Arslan, Gaihbe, and Kadouri [5] used new and improved equipment to monitor soil salinity, soil water content, and other soil-plantwater properties. Malash, Flowers, and Ragab [6] studied the effect of two water management strategies i.e. alternated and mixed supply of fresh and saline drainage water applied through drip and furrow method on tomato yield and growth. Ould, Yamamoto, Rasiah, Inoue, and Anyoji [7] inputted the effect of two levels of irrigation input, were assessed on sorghum grain yield as impacted by available soil water after irrigation and the electrical conductivity of soil water in sand, in a greenhouse experiment. Melissa B. Haley, Michael D. Dukes, and Grady L. Miller [8] documented residential irrigation water use in the Central Florida ridge region on typical residential landscapes. Kuscu H., Bölüktepe F., and Demir A. [9] assessed the performance of irrigation water management of the Bursa-Karacabey irrigation scheme located in the western Turkey. FRANK A. WARD [10] reviewed research on factors affecting the level and value of irrigation infrastructure investments, policy instruments for sustaining irrigation infrastructure, considering both market and institutional approaches. Felix B Reinders [11] studied and researched over 40 years, on the techniques of flood and microirrigation had contributed to the knowledge base of applying irrigation methods correctly. Staff Report [12] estimated potential new water from agricultural water use efficiency is 1.3 percent of the current amount used by the state's farmers. Skhiri A and Dechmi F [13] assessed irrigation performance to identify sprinkler irrigation water management impact on surface and subsurface water losses during two years, using various water management indexes. Fátima Moreno-Pérez, and José Roldán-Ca nas [14] examined irrigation water management in the Genil-Cabra Irrigation District of the Province of Cordoba (southern Spain) using three irrigation indicators.

This present paper aims to improve irrigation water management by two stages of management, the first stage is irrigation scheduling by calculating eapo-transpiration and studying the effect of relative evapotranspiration on relative yield of crop and the effect of depth of water irrigation on the net revenue. The second stages focuses on the effect of mixing and alternative irrigation water management strategies of fresh and saline irrigation water applied through different irrigation systems on productivity of crops in Delta of Egypt. 


\subsection{Study Area}

\section{Study Area And Associated Water Management}

The study area corresponds to a water management area, the Delta of Egypt as shown in Fig.1. It is the Nile Delta formed in Northern Egypt where the Nile River spreads out and drains into the Mediterranean Sea. It is one of the world's largest river deltas, from Alexandria in the west to Port Said in the east. The Nile is considered to be an arc-shaped delta, as it resembles a triangle or lotus flower when seen from above.

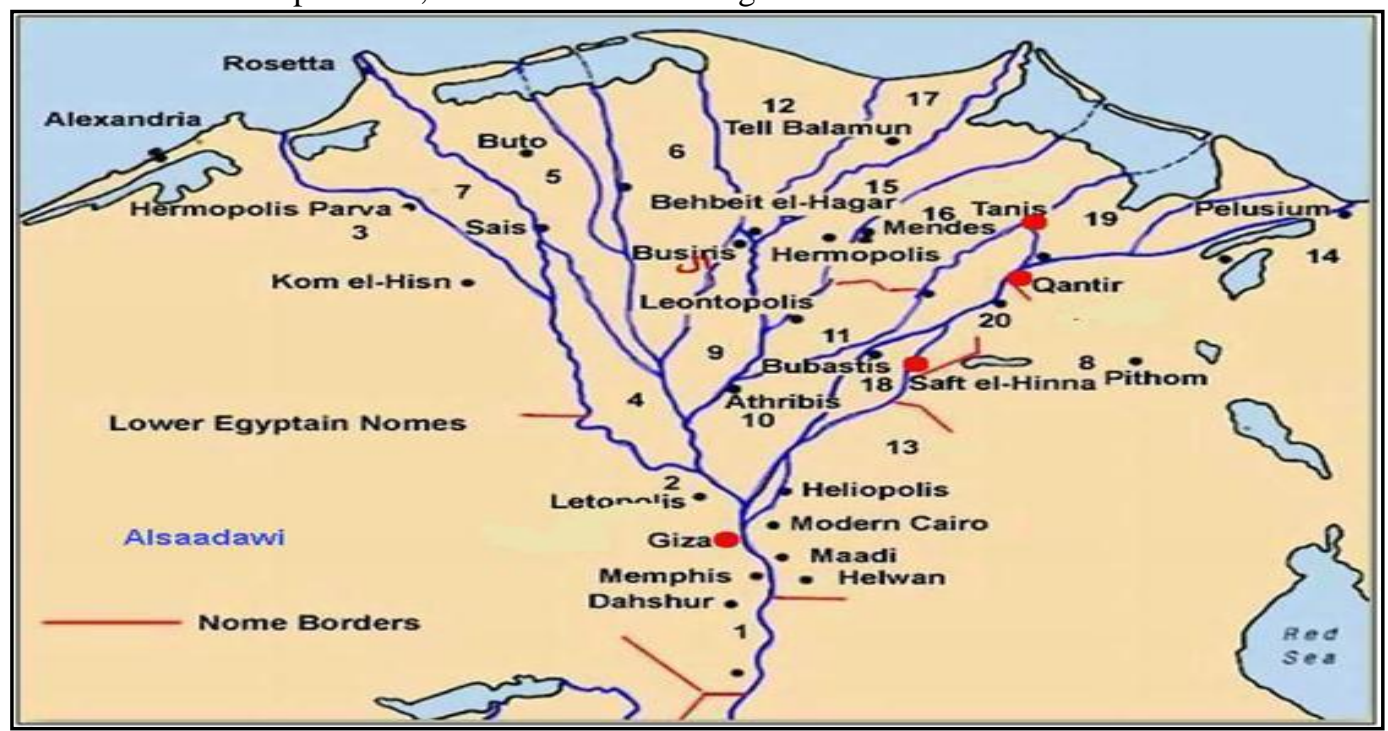

Fig.1 Reference Map of the Delta of Egypt

\subsection{Cropping pattern in the Delta of Egypt}

The major cropping seasons are the winter (November to May) and the summer (May to October) seasons. The main winter crops are wheat, Egyptian clover (berseem), and the main summer crops are cotton, rice and maize. There are two patterns of crop rotation practiced with, and without, rice. When both these rotation patterns are firmly applied for three successive years, fertilizer demands would be reduced [15].

\subsection{Soil}

The soils of Egypt comprise the alluvial soils of the Delta and Valley, the calcareous soils along the coastal littoral of Egypt, the soils of the Eastern and Western Deserts as well as the soils of Sinai Peninsula. There exist two geomorphic units in the central part of the Delta, namely the young deltaic plain and the Mediterranean coastal plain. The clay that covers the flat floor of the valley and most surface of the Delta forming the arable land of Egypt has all been deposited by the floodwater in the course of the recent geological period.

\subsection{Water Quality in Egypt}

Industrial effluents contribute to the increased levels of trace elements especially after the construction of the high dam where the potential for flushing the contaminated sediments during the flood period was eliminated. Drainage return flow to the Nile result into an increase in salinity of the water. The quality of water for irrigation purposes is generally determined by its salt content, bicarbonate concentration, and the presence of potentially toxic elements.

\subsection{Water Cost}

Surface-water prices are generally based on operation and maintenance costs of the delivery system. Deliveries are often charged on a fixed rate per irrigated acre, and are not necessarily adjusted for reduced water demand with improved management. Groundwater costs are generally limited to the cost of access variable and fixed cost of pumping and vary greatly depending on well yield, pump lift, and power source.

\subsection{Irrigation improvement projects in the old lands in Egypt}

The alluvial soils of the Nile Valley and Delta reduce the possibility of changing existing gravity irrigation into modern systems. The reason for this is:

- The very low permeability of the soils and the high possibility of soil salinity;

- The high initial cost of the imported material (sprinklers, drippers, filters, fertilizers,...etc) and the high cost of energy, maintenance and spare parts; 
- The need for skilled labor;

- The need to raise crops of relatively low return like wheat and maize. Other cash crops like vegetables and flowers are not easily marketed in the surrounding area;

For these reasons, the state has supported the improvement of surface irrigation in the old lands.

\section{Materials and Methods}

This research covers 2 levels of water management infrastructure:

1.Irrigation scheduling,

2. Salinity water.

\subsection{Irrigation scheduling}

Irrigation scheduling is a generic term applied to any technique that is intended to aid farmer in determining when and how much to irrigate. Irrigation scheduling can be practiced in a number of ways, some very expensive and complex, some very cheap and simple. Irrigation scheduling is always listed as an effective management practice that can improve field irrigation efficiency. Many factors are involved in irrigation management, including water availability, product prices and market uncertainties, plus the constraints imposed by agrarian policies. All these factors should be considered when designing an irrigation schedule.

The timing and volume of irrigation must be specified according to standard scheduling criteria which works with the main crops of the study area, including field crops (berseem, wheat, maize, cotton, rice), which occupy a large area and use a large share of the water resources. Water management plans must include deficit irrigation strategies searching maximum gross margin instead of maximum yield.

This research is composed by two models:

1- Model I employs a relationship between relative irrigation depths and relative crop yield, and the gross margin is related to the irrigation depth for each crop and for different water cost, considering the irrigation system evaluation. Fig. 2 shows the general diagram of irrigation scheduling which study in this research.

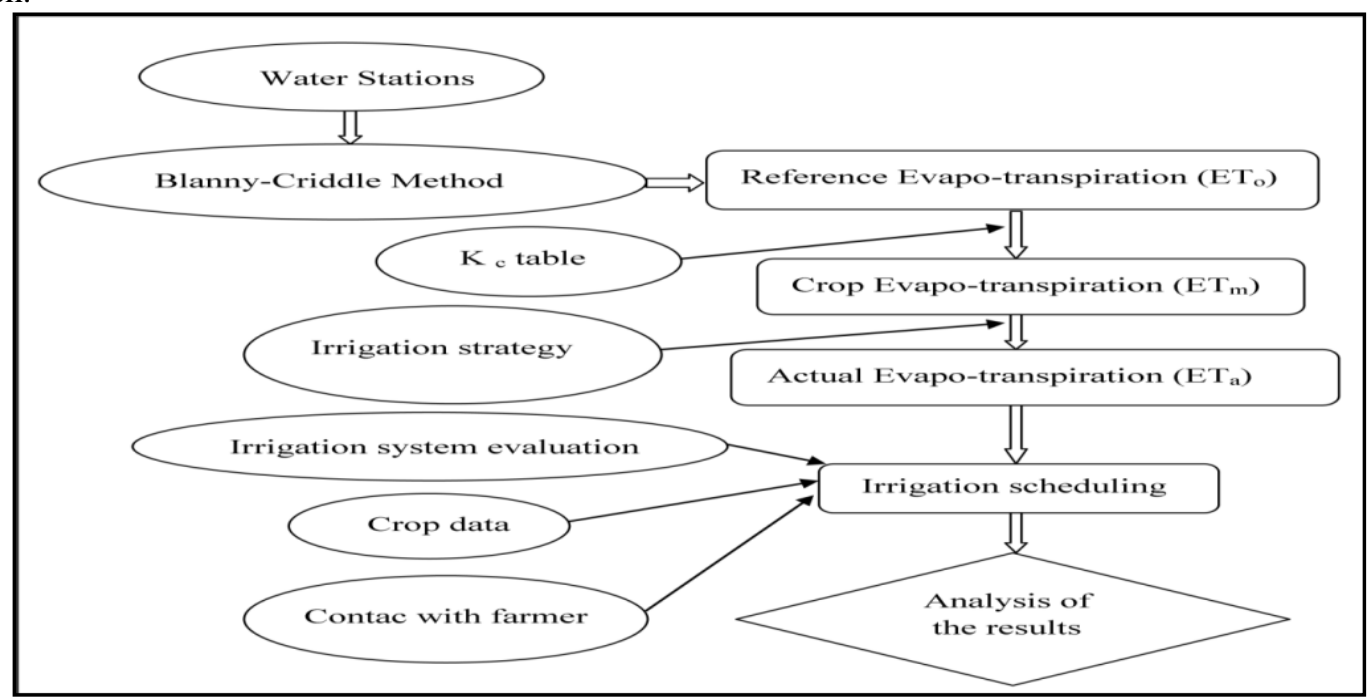

Fig.2 Diagram of Irrigation Scheduling for Delta of Egypt

2- Model II identifies cropping rotation and irrigation strategies that maximize total profits at the farm level. This model uses the relation between gross margin and the irrigation depth for an individual crop to optimize crop rotation on the whole farm. Crop rotation must satisfy certain restrictions: (a) available area on the farm, (b) maximum or minimum area for the different crops considered, (c) availability of irrigation water, and (d) environmental constraints. All these restrictions should ensure that the simulation setting reflects the real situation.

\subsubsection{Model I:}

The functions of this computing model are the following:

a- Determination of reference evapo-transpiration $\left(\mathrm{ET}_{\mathrm{o}}\right)$,

b- The crop evapo-transpiration $\left(\mathrm{ET}_{\mathrm{m}}\right)$ for the different crops in the study area is determined from the crop coefficient $\left(\mathrm{K}_{\mathrm{c}}\right)$.

c- The relationship between crop yield and evapo-transpiration.

d- Yields and crop prices are used to estimate the farmer's gross revenue. 
e- Field irrigation systems evaluations.

$\mathrm{ET}_{\mathrm{o}}$ is calculated using the Blanny-Criddle method [16] as follow:

$$
\mathrm{ET}_{\mathrm{o}}=\mathrm{P} *\left(0.46 * \mathrm{~T}_{\text {mean }}+8\right)
$$

Where,

$\mathrm{ET}_{\mathrm{o}}$ : Reference evapo-transpiration (mm/day),

P: mean daily percentage of annual daytime hours,

$\mathrm{T}_{\text {mean }}$ : mean daily temperature $\left({ }^{\circ} \mathrm{C}\right)$

The crop evapo-transpiration $\left(\mathrm{ET}_{\mathrm{m}}\right)$ for the different crops is determined from the crop coefficient $\left(\mathrm{K}_{\mathrm{c}}\right)$ [16] as follow

Where,

$$
\mathrm{ET}_{\mathrm{m}}=\mathrm{K}_{\mathrm{c}} * \mathrm{ET}_{\mathrm{o}}
$$

$\mathrm{ET}_{\mathrm{m}}$ : maximum evapo-transpiration $(\mathrm{mm})$

The production function [17], which estimates the crop yield based on the relation of actual to maximum evapo-transpiration is as:

$$
1-\frac{\mathrm{Y}_{\mathrm{a}}}{\mathrm{Y}_{\mathrm{m}}}=\mathrm{K}_{\mathrm{y}} *\left(1-\frac{E \mathrm{~T}_{\mathrm{a}}}{E \mathrm{~T}_{\mathrm{m}}}\right)^{2}
$$

Where:

$\mathrm{Y}_{\mathrm{a}}$ : is the real harvested yield $(\mathrm{kg} / \mathrm{ha})$

$\mathrm{Y}_{\mathrm{m}}$ : is the agronomic maximum yield that can be achieved in a given area when crop development is not limited by water availability or other factors $(\mathrm{kg} / \mathrm{ha})$

$\mathrm{K}_{\mathrm{y}}$ : a yield response factor from FAO Irrigation and Drainage [18]

$\mathrm{ET}_{\mathrm{a}}$ : is the actual crop evapo-transpiration ( $\left.\mathrm{mm}\right)$

Cropping costs linked to yield, and therefore, indirectly linked to applied water, are treated as a function of yield. Global production costs include all the costs associated with the agricultural production process, the global production costs include the production costs (fertilizers, seeds, treatments, insurances, and lease) and the cost of money invested temporarily in each agricultural production campaign. By analyzing the different yield objectives, the costs are modeled as a function of the crop yield. The gross margin is obtained from the commercial products plus the possible subsidies minus the production costs [4]:

Where

$$
\mathrm{GM}=\mathrm{YP}_{\mathrm{p}}-\mathrm{Pc}-\mathrm{C}_{\mathrm{w}} \mathrm{D}_{\mathrm{g}}
$$

GM: is the gross margin (LE/feddan),

$\mathrm{Y}$ : are the real harvested yield /feddan,

$\mathrm{P}_{\mathrm{p}}$ : is the price of the product,

Pc: is the global production costs for actual yield (LE/ feddan),

$\mathrm{C}_{\mathrm{w}}$ : is the cost of irrigation water application $\left(\mathrm{LE} / \mathrm{m}^{3}\right),(=0.15-0.20 \mathrm{LE})$

$\mathrm{D}_{\mathrm{g}}$ : is the gross depth applied by the system $\left(\mathrm{m}^{3} /\right.$ feddan).

The real harvested yield, the price of the product, and the global production costs for actual yield for each crop are shown in Table 1. The relation between the gross margin and the gross irrigation depth (Eq. (4)) allows us to analyze the water irrigation depth that maximizes the gross margin.

Irrigation evaluations make possible to identify problems or deficiencies in the irrigation systems, which should be solved to improve irrigation efficiency. This level is achieved only in farms where the farmer requests a personalized irrigation scheduling, including information about the irrigation set time. The most important major option for reducing field applications is to improve irrigation efficiency. This can involve improving management of the existing system or changing to an irrigation system that makes it easier to achieve the potential efficiency of the system.

Table 1, Real Harvested Yield, the Price of the Product, and the Global Production Costs for Actual Yield for each Crop

\begin{tabular}{|l|l|l|l|}
\hline Crop & Y/feddan & Pp (LE) & Pc (LE/feddan) \\
\hline Cotton & 9 kantar & 1200 & 6600 \\
\hline Maize & 28 ardab & 350 & 4850 \\
\hline Rice & 4 ton & 2000 & 3250 \\
\hline Wheat & 20 ardab & 400 & 4700 \\
\hline Berseem & 60 ton & 140 & 4200 \\
\hline Source: National Agricultural Income, 2012; Agricultural Statistics. \\
\hline
\end{tabular}


Distribution network and on-farm irrigation systems, both levels must be correctly designed, maintained and managed to achieve high-irrigation performance. When dealing with farm irrigation systems, water must be applied with high uniformity and efficiency, while evaluation is necessary in order to identify possible problems. Likewise, it is necessary to advice farmers concerning management so that efficiency parameters can be improved (e.g. determining the time of sprinkler irrigation in order to decrease drift and evaporation losses). It should be evident that achieving high irrigation efficiency with an irrigation system in disrepair will be difficult if not impossible. Different irrigation system types have different aspects to maintenance. The following are some of the more important aspects for system maintenance:

a-For flood irrigation systems:

- Maintaining a smooth field surface graded to the appropriate slope.

- Sufficient flow delivery capacity.

- Maintaining sufficient drainage and/or tail water return system capacity.

b- For sprinkler systems:

- Insuring that the correct nozzle size is used throughout a field.

- Insuring that nozzles are not excessively worn or clogged.

- Insuring that correct pressures are maintained during the irrigation.

c- For micro systems:

- Insuring the correct number and type of emission device.

- Insuring that system pressures are correct.

- Insuring that emission devices are not worn or clogged.

\subsubsection{Model II}

In general, there is a high percentage of horticultural crops (garlic, onion, potato, etc.) included in the rotational crops, thus, replacing the traditional field crops in the area, which are economically compensatory payments (maize, wheat, etc.). The woody crops, such as vineyards or olives trees, are interesting as well. When the mean availability of water resources is reduced, dry farming becomes part of the optimum strategy in average climatic years, while crops with high gross margin are usually well irrigated. Also, in the selected crop rotations when scarce and expensive water, an economic optimization criteria must be used. Both levels must be correctly designed, maintained and managed to achieve high-irrigation performance. The distribution network must ensure that the required flows are available timely, according to the crop water requirements for any type of water delivery scheme. When dealing with farm irrigation systems, water must be applied with high uniformity and efficiency, while evaluation is necessary in order to identify possible problems. Likewise, it is necessary to advice farmers concerning management so that efficiency parameters can be improved (e.g. determining the time of sprinkler irrigation in order to decrease drift and evaporation losses).

\subsection{Salinity Water}

All major irrigation water sources contain dissolved salts. These salts include a variety of natural occurring dissolved minerals, which can vary with location, time, and water source. Many of these mineral salts are micronutrients, having beneficial effects. However, excessive total salt concentration or excessive levels of some potentially toxic elements can have detrimental effects on plant health and/or soil conditions. The term "salinity" is used to describe the concentration of salt species, generally including: calcium $\left(\mathrm{Ca}^{+2}\right)$, magnesium $\left(\mathrm{Mg}^{+2}\right)$, sodium $\left(\mathrm{Na}^{+}\right)$, potassium $\left(\mathrm{K}^{+}\right)$, chloride $\left(\mathrm{Cl}^{-}\right)$, bicarbonate $\left(\mathrm{HCO}^{-3}\right)$, carbonate $\left(\mathrm{CO}_{3}^{-2}\right)$, sulfate $\left(\mathrm{SO}_{4}^{-2}\right)$ and others. Salinity is expressed in terms of electrical conductivity (EC), in units of millimhos per centimeter $(\mathrm{mmhos} / \mathrm{cm})$. Although certain ions are toxic to crops, the crop stress effects caused by accumulation of salts in the root zone are mainly dependent on total salt concentration in soil water. Tolerance of crops to salinity varies between crops and also with stage of growth. In this research, the winter crops (such as wheat, long berseem and short berseem) and summer crops (such as rice and maize) and their salinity as shown in Table 2 are studied.

Table2, Different Crops in the Study Area and its Salinity

\begin{tabular}{|l|l|l|l|l|l|}
\hline \multicolumn{2}{|c|}{ Crops } & \multicolumn{2}{|l|}{$\mathrm{EC}_{\mathrm{e}}(\mathrm{mmhos} / \mathrm{cm})$} & \multirow{2}{*}{$\mathrm{EC}_{\mathrm{e}}$} \\
\cline { 3 - 5 } & & $0-0.25 \mathrm{~m}$ & $0.25-0.5 \mathrm{~m}$ & $0.5-1 \mathrm{~m}$ & \\
\hline \multirow{3}{*}{ Winter Crop } & Wheat & 2.58 & 3.46 & 3.96 & 3.33 \\
\cline { 2 - 5 } & Long Berseem & 1.07 & 1.04 & 1 & 1.04 \\
\cline { 2 - 5 } & Short Berseem & 0.69 & 0.617 & 0.52 & 0.61 \\
\hline \multirow{3}{*}{ Summer Crop } & Rice & 1.37 & 1.06 & & 1.22 \\
\cline { 2 - 5 } & Maize & 0.844 & 0.99 & & 0.92 \\
\hline
\end{tabular}

Source: Ministry of Agriculture, Department of Agricultural Economics Issue No.3, Cairo, Egypt 
Three water management strategies are used: apply mixed saline drainage water $(4.6-7.8 \mathrm{mmhos} / \mathrm{cm})$, moderately sewage water $(7.8-23.44 \mathrm{mmhos} / \mathrm{cm})$, and fresh water $(1.56 \mathrm{mmhos} / \mathrm{cm})$ and alternate supply of fresh and saline water in six ratios:
$1-100 \%$ fresh;
3- $60 \%$ fresh and $40 \%$ saline;
2- $80 \%$ fresh and $20 \%$ saline;
5- $20 \%$ fresh and $80 \%$ saline;
4- $40 \%$ fresh and $60 \%$ saline;
6- $100 \%$ saline.

The relation between salinity of irrigation water $\left(\mathrm{EC}_{\mathrm{w}}\right)$ and soil salinity level $\left(\mathrm{EC}_{\mathrm{e}}\right)$ [19] is: $\mathrm{EC}_{\mathrm{e}}=1.5 \mathrm{EC}_{\mathrm{w}}$

Where:

$\mathrm{EC}_{\mathrm{e}}=$ average soil salinity in root zone (saturated soil extract basis, mmhos $/ \mathrm{cm}$ )

$\mathrm{EC}_{\mathrm{w}}=$ salinity of applied irrigation water (mmhos/cm)

The relation between crop yield and soil salinity can be represented by the following equation [20]:

$$
\mathrm{Y} / \mathrm{Y}_{\mathrm{m}}=100-\mathrm{B}\left(\mathrm{EC}_{\mathrm{e}}-\mathrm{A}\right)
$$

Where:

$\mathrm{Y}=$ relative yield $(\%)$.

$\mathrm{Y}_{\mathrm{m}}=$ maximum yield obtained with good water.

$\mathrm{A}=$ salinity threshold $(\mathrm{mmhos} / \mathrm{cm})$ beyond which there is a yield decrease .

$\mathrm{B}=$ percent yield decrease per unit increase in salinity $(\mathrm{mmhos} / \mathrm{cm})$.

According to Maas and Hoffman (1977), the value of the threshold A is $7.7 \mathrm{mmhos} / \mathrm{cm}$ for cotton (summer crop) and $6.6 \mathrm{mmhos} / \mathrm{cm}$ for wheat (winter crop), and the yield decrease B is $5.2 \%$ per mmhos $/ \mathrm{cm}$.

The effect of suggested alternative of irrigation applications on soil salinity and crop yield is studied as shown in Table 3. A handheld electrical conductivity meter is used to measure salt content of irrigation water by this equation [21]:

$$
\mathrm{TDS}=44.84+\left(633 \times \mathrm{EC}_{\mathrm{w}}\right)
$$

Where: TDS: is the total dissolved salts in parts per million (ppm).

Table 3, Summary Table Indicating the Effect of the Different Irrigation Water Alternatives on Soil

\begin{tabular}{|c|c|c|c|c|c|c|c|}
\hline \multicolumn{2}{|l|}{ Alternatives } & $\begin{array}{l}100 \% \\
\text { fresh }\end{array}$ & $\begin{array}{l}80 \% \text { fresh \& } \\
20 \% \text { saline }\end{array}$ & $\begin{array}{lr}60 \% & \text { fresh } \\
\& & 40 \% \\
\text { saline } & \end{array}$ & $\begin{array}{l}40 \% \\
\text { fresh \& } \\
60 \% \\
\text { saline }\end{array}$ & $\begin{array}{l}20 \% \\
\text { fresh \& } \\
80 \% \\
\text { saline }\end{array}$ & $\begin{array}{l}100 \% \\
\text { saline }\end{array}$ \\
\hline \multirow[t]{2}{*}{$\mathrm{EC}_{\mathrm{w}}(\mathrm{mmhos} / \mathrm{cm})$} & $\begin{array}{l}\text { drainage } \\
\text { water }=6.25\end{array}$ & 1.56 & 2.50 & 3.44 & 4.37 & 5.31 & 6.25 \\
\hline & $\begin{array}{l}\text { sewage water } \\
=15.62\end{array}$ & 1.56 & 4.37 & 7.18 & 10.00 & 12.81 & 15.62 \\
\hline Drainage water & $\mathrm{EC}_{\mathrm{e}}=1.5 \mathrm{EC}_{\mathrm{w}}$ & 2.34 & 3.75 & 5.15 & 6.56 & 7.97 & 9.38 \\
\hline \multirow[t]{5}{*}{$\mathrm{EC}_{\mathrm{e}}(\mathrm{mmhos} / \mathrm{cm})$} & Wheat & 5.67 & 7.08 & 8.49 & 9.89 & 11.30 & 12.71 \\
\hline & long berseem & 3.38 & 4.78 & 6.19 & 7.60 & 9.00 & 10.41 \\
\hline & short berseem & 2.95 & 4.36 & 5.76 & 7.17 & 8.58 & 9.98 \\
\hline & Rice & 3.56 & 4.96 & 6.37 & 7.78 & 9.18 & 10.59 \\
\hline & Maize & 3.26 & 4.66 & 6.07 & 7.48 & 8.89 & 10.29 \\
\hline \multirow{5}{*}{$\mathrm{Y} / \mathrm{Y}_{\mathrm{m}}(\%)$} & Wheat & 104.82 & 97.50 & 90.19 & 82.87 & 75.55 & 68.24 \\
\hline & long berseem & 116.76 & 109.44 & 102.13 & 94.81 & 87.50 & 80.18 \\
\hline & short berseem & 118.99 & 111.67 & 104.35 & 97.04 & 89.72 & 82.40 \\
\hline & Rice & 121.55 & 114.24 & 106.92 & 99.60 & 92.29 & 84.97 \\
\hline & Maize & 123.10 & 115.79 & 108.47 & 101.15 & 93.84 & 86.52 \\
\hline Sewage water & $\mathrm{EC}_{\mathrm{e}}=1.5 \mathrm{EC}_{\mathrm{w}}$ & 2.34 & 6.56 & 10.78 & 14.99 & 19.21 & 23.43 \\
\hline \multirow[t]{5}{*}{$\mathrm{EC}_{\mathrm{e}}(\mathrm{mmhos} / \mathrm{cm})$} & Wheat & 5.67 & 9.89 & 14.11 & 18.33 & 22.55 & 26.76 \\
\hline & long berseem & 3.38 & 7.59 & 11.81 & 16.03 & 20.25 & 24.47 \\
\hline & short berseem & 2.95 & 7.17 & 11.39 & 15.60 & 19.82 & 24.04 \\
\hline & Rice & 3.56 & 7.77 & 11.99 & 16.21 & 20.43 & 24.65 \\
\hline & Maize & 3.26 & 7.48 & 11.69 & 15.91 & 20.13 & 24.35 \\
\hline \multirow[t]{5}{*}{$\mathrm{Y} / \mathrm{Y}_{\mathrm{m}}(\%)$} & Wheat & 104.82 & 82.89 & 60.95 & 39.02 & 17.08 & -4.85 \\
\hline & long berseem & 116.76 & 94.83 & 72.89 & 50.96 & 29.03 & 7.09 \\
\hline & short berseem & 118.99 & 97.05 & 75.12 & 53.18 & 31.25 & 9.32 \\
\hline & Rice & 121.55 & 99.62 & 77.69 & 55.75 & 33.82 & 11.89 \\
\hline & Maize & 123.10 & 101.17 & 79.24 & 57.30 & 35.37 & 13.44 \\
\hline
\end{tabular}
Salinity and Crop Yields 
The accumulated salt in the soil due to the different alternatives of irrigation water is calculated in Table 4. The solution to salinity management in the field is through leaching (washing) accumulated salts below the root zone. This is often accomplished by occasional excessive irrigation applications to dissolve, and move the salts. The amount of excess irrigation application required (often referred to as the leaching fraction) depends upon the concentrations of salts within the soil and in the water applied to accomplish the leaching. To estimate the leaching requirement (LR), with a given salinity of irrigation water $\left(\mathrm{EC}_{\mathrm{w}}\right)$ and an acceptable soil salinity level $\left(\mathrm{EC}_{\mathrm{e}}\right)[21]$, as the following:

$$
\mathrm{LR}=\frac{\mathrm{EC}_{\mathrm{w}}}{5\left(\mathrm{EC}_{\mathrm{e}}\right)-\mathrm{EC}_{\mathrm{w}}}
$$

Where:

$\mathrm{LR}=$ leaching requirement/fraction $(\%)$

Table 4, Accumulated Salt in the Soil due to the Different Irrigation Water Alternatives

\begin{tabular}{|l|c|c|c|c|}
\hline \multirow{2}{*}{ Alternatives } & \multicolumn{2}{|c|}{ Drainage water } & \multicolumn{2}{c|}{ Sewage water } \\
\cline { 2 - 5 } & $\mathrm{EC}_{\mathrm{w}}(\mathrm{ppm})$ & $\mathrm{TDS}$ (tons) & $\mathrm{EC}_{\mathrm{w}}(\mathrm{ppm})$ & $\mathrm{TDS}$ (tons) \\
\hline $100 \%$ fresh & 998.4 & 0.63 & 998.4 & 0.63 \\
\hline $80 \%$ fresh and 20\% saline & 1598.72 & 1.01 & 2798.08 & 1.77 \\
\hline $60 \%$ fresh and 40\% saline & 2199.04 & 1.39 & 4597.76 & 2.91 \\
\hline $40 \%$ fresh and 60\% saline & 2799.36 & 1.77 & 6397.44 & 4.05 \\
\hline $20 \%$ fresh and 80\% saline & 3399.68 & 2.15 & 8197.12 & 5.19 \\
\hline $100 \%$ saline & 4000 & 2.53 & 9996.8 & 6.33 \\
\hline
\end{tabular}

The leaching requirements for winter and summer crops which studied in this research are calculated using above equation for the different alternatives of irrigation water and summarized in Table 5.

Table 5, Leaching Requirements for Different Crops for the Different Alternatives of Irrigation Water

\begin{tabular}{|c|c|c|c|c|c|c|c|}
\hline \multicolumn{2}{|c|}{ Alternatives } & \multirow{2}{*}{$\begin{array}{l}100 \% \\
\text { fresh } \\
1.56\end{array}$} & \multirow{2}{*}{$\begin{array}{l}80 \% \text { fresh \& } \\
20 \% \text { saline } \\
2.5\end{array}$} & \multirow{2}{*}{$\begin{array}{l}60 \% \text { fresh \& } \\
40 \% \text { saline } \\
3.44\end{array}$} & \multirow{2}{*}{$\begin{array}{l}40 \% \text { fresh \& } \\
60 \% \text { saline } \\
4.37\end{array}$} & \multirow{2}{*}{$\begin{array}{l}20 \% \text { fresh \& } \\
80 \% \text { saline } \\
5.31\end{array}$} & \multirow{2}{*}{$\begin{array}{l}100 \% \\
\text { saline } \\
6.25\end{array}$} \\
\hline $\begin{array}{l}\text { Drainage } \\
\text { water }\end{array}$ & $\mathrm{EC}_{\mathrm{w}}$ & & & & & & \\
\hline \multirow[t]{2}{*}{ Wheat } & $\mathrm{EC}_{\mathrm{e}}$ & 5.67 & 7.08 & 8.49 & 9.89 & 11.3 & 12.71 \\
\hline & LR\% & 5.82 & 7.59 & 8.81 & 9.7 & 10.38 & 10.91 \\
\hline \multirow{2}{*}{$\begin{array}{l}\text { Long } \\
\text { Berseem }\end{array}$} & $\mathrm{EC}_{\mathrm{e}}$ & 3.38 & 4.78 & 6.19 & 7.6 & 9 & 10.41 \\
\hline & LR\% & 10.18 & 11.67 & 12.49 & 13.01 & 13.38 & 13.65 \\
\hline \multirow{2}{*}{$\begin{array}{l}\text { Short } \\
\text { Berseem }\end{array}$} & $\mathrm{EC}_{\mathrm{e}}$ & 2.94 & 4.36 & 5.76 & 7.17 & 8.58 & 9.98 \\
\hline & LR\% & 11.87 & 12.94 & 13.55 & 13.9 & 14.13 & 14.32 \\
\hline \multirow[t]{2}{*}{ Rice } & $\mathrm{EC}_{\mathrm{e}}$ & 3.56 & 4.96 & 6.37 & 7.78 & 9.18 & 10.59 \\
\hline & LR\% & 9.61 & 11.2 & 12.09 & 12.67 & 13.09 & 13.38 \\
\hline \multirow[t]{2}{*}{ Maize } & $\mathrm{EC}_{\mathrm{e}}$ & 3.26 & 4.66 & 6.07 & 7.48 & 8.89 & 10.29 \\
\hline & LR\% & 10.58 & 12.01 & 12.77 & 13.24 & 13.57 & 13.83 \\
\hline $\begin{array}{l}\text { Sewage } \\
\text { water }\end{array}$ & $\mathrm{EC}_{\mathrm{w}}$ & 1.56 & 4.37 & 7.18 & 10 & 12.81 & 15.62 \\
\hline \multirow[t]{2}{*}{ Wheat } & $\mathrm{EC}_{\mathrm{e}}$ & 5.67 & 9.89 & 14.11 & 18.33 & 22.55 & 26.67 \\
\hline & LR\% & 5.82 & 9.7 & 11.34 & 12.24 & 12.82 & 13.22 \\
\hline \multirow{2}{*}{$\begin{array}{l}\text { Long } \\
\text { Berseem }\end{array}$} & $\mathrm{EC}_{\mathrm{e}}$ & 3.38 & 7.59 & 11.81 & 16.03 & 20.25 & 24.47 \\
\hline & LR\% & 10.18 & 13.02 & 13.85 & 14.25 & 14.48 & 14.64 \\
\hline \multirow{2}{*}{$\begin{array}{l}\text { Short } \\
\text { Berseem }\end{array}$} & $\mathrm{EC}_{\mathrm{e}}$ & 2.94 & 7.17 & 11.39 & 15.6 & 19.82 & 24.04 \\
\hline & LR\% & 11.87 & 13.89 & 14.44 & 14.7 & 14.84 & 14.94 \\
\hline \multirow[t]{2}{*}{ Rice } & $\mathrm{EC}_{\mathrm{e}}$ & 3.56 & 7.77 & 11.99 & 16.21 & 20.43 & 24.65 \\
\hline & LR & 9.61 & 12.68 & 13.61 & 14.07 & 14.34 & 14.51 \\
\hline \multirow[t]{2}{*}{ Maize } & $\mathrm{EC}_{\mathrm{e}}$ & 3.26 & 7.48 & 11.96 & 15.91 & 20.13 & 24.35 \\
\hline & LR & 10.58 & 13.24 & 14.01 & 14.37 & 14.58 & 14.72 \\
\hline
\end{tabular}




\section{Results and Discussion}

\subsection{The results of irrigation schedule:}

One of the main activities of this research is to assess the water requirements of crops and, if personalized cooperation exists, to carry out the irrigation scheduling. The two main strategies results to quantify the water requirements and irrigation scheduling are as follows:

\subsubsection{Model I:}

a-The relation between relative crop yield and irrigation water depth for the crops which cultivate in the study area (rice, maize, cotton, wheat, and berseem) is shown in Fig 3. It results that:

For cotton crop when actual evapo-transpiration $\left(\mathrm{ET}_{\mathrm{a}}\right)$ is $20 \%$ of maximum evapo-transpiration $\left(\mathrm{ET}_{\mathrm{m}}\right)$, the yield $\left(\mathrm{Y}_{\mathrm{a}}\right)$ is $45 \%$ of maximum yield of crop $\left(\mathrm{Y}_{\mathrm{m}}\right)$, when $\mathrm{ET}_{\mathrm{a}}=40 \% \mathrm{ET}_{\mathrm{m}}$, the $\mathrm{Y}_{\mathrm{a}}=70 \% \mathrm{Y}_{\mathrm{m}}$, when $\mathrm{ET}_{\mathrm{a}}=$ $60 \% \mathrm{ET}_{\mathrm{m}}$, the $\mathrm{Y}_{\mathrm{a}}=85 \% \mathrm{Y}_{\mathrm{m}}$, when $\mathrm{ET}_{\mathrm{a}}=80 \% \mathrm{ET}_{\mathrm{m}}$, the $\mathrm{Y}_{\mathrm{a}}=95 \% \mathrm{Y}_{\mathrm{m}}$, when $\mathrm{ET}_{\mathrm{a}}=100 \% \mathrm{ET}_{\mathrm{m}}$ the $\mathrm{Y}_{\mathrm{a}}=100 \% \mathrm{Y}_{\mathrm{m}}$.

For maize crop when $\mathrm{ET}_{\mathrm{a}}=20 \% \mathrm{ET}_{\mathrm{m}}$, the $\mathrm{Y}_{\mathrm{a}}=20 \% \mathrm{Y}_{\mathrm{m}}$, when $\mathrm{ET}_{\mathrm{a}}=40 \% \mathrm{ET}_{\mathrm{m}}$ the $\mathrm{Y}_{\mathrm{a}}=55 \% \mathrm{Y}_{\mathrm{m}}$, when $E_{a}=60 \% E T_{m}$, the $Y_{a}=80 \% Y_{m}$, when $E_{a}=80 \% E T_{m}$ the $Y_{a}=95 \% Y_{m}$, when $E_{a}=100 \% E T_{m}$, the $Y_{a}=100 \% Y_{m}$.

For rice crop when actual evapo-transpiration $\left(\mathrm{ET}_{\mathrm{a}}\right)$ is $20 \%$ of maximum evapo-transpiration $\left(\mathrm{ET}_{\mathrm{m}}\right)$, $\mathrm{Y}_{\mathrm{a}}=5 \% \mathrm{Y}_{\mathrm{m}}$, when $\mathrm{ET}_{\mathrm{a}}=40 \% \mathrm{ET}_{\mathrm{m}}, \mathrm{Y}_{\mathrm{a}}=30 \% \mathrm{Y}_{\mathrm{m}}$, when $\mathrm{ET}_{\mathrm{a}}=60 \% \mathrm{ET}_{\mathrm{m}}, \mathrm{Y}_{\mathrm{a}}=52 \% \mathrm{Y}_{\mathrm{m}}$, when $\mathrm{ET}_{\mathrm{a}}=80 \% \mathrm{ET}_{\mathrm{m}}$, $\mathrm{Y}_{\mathrm{a}}=78 \% \mathrm{Y}_{\mathrm{m}}$, when $\mathrm{ET}_{\mathrm{a}}=100 \% \mathrm{ET}_{\mathrm{m}}, \mathrm{Y}_{\mathrm{a}}=100 \% \mathrm{Y}_{\mathrm{m}}$.

For berseem crop when $\mathrm{ET}_{\mathrm{a}}=20 \% \mathrm{ET}_{\mathrm{m}}, \mathrm{Y}_{\mathrm{a}}=30 \% \mathrm{Y}_{\mathrm{m}}$, when $\mathrm{ET}_{\mathrm{a}}=40 \% \mathrm{ET}_{\mathrm{m}}, \mathrm{Y}_{\mathrm{a}}=60 \% \mathrm{Y}_{\mathrm{m}}$, when $\mathrm{ET}_{\mathrm{a}}=60 \% \mathrm{ET}_{\mathrm{m}}, \mathrm{Y}_{\mathrm{a}}=82 \% \mathrm{Y}_{\mathrm{m}}$, when $\mathrm{ET}_{\mathrm{a}}=80 \% \mathrm{ET}_{\mathrm{m}}, \mathrm{Y}_{\mathrm{a}}=95 \% \mathrm{Y}_{\mathrm{m}}$, when $\mathrm{ET}_{\mathrm{a}}=100 \% \mathrm{ET}_{\mathrm{m}}, \mathrm{Y}_{\mathrm{a}}=100 \% \mathrm{Y}_{\mathrm{m}}$.

For wheat crop when $\mathrm{ET}_{\mathrm{a}}=20 \% \mathrm{ET}_{\mathrm{m}}, \mathrm{Y}_{\mathrm{a}}=32 \% \mathrm{Y}_{\mathrm{m}}$, when $\mathrm{ET}_{\mathrm{a}}=40 \% \mathrm{ET}_{\mathrm{m}}, \mathrm{Y}_{\mathrm{a}}=62 \% \mathrm{Y}_{\mathrm{m}}$, when $\mathrm{ET}_{\mathrm{a}}=60 \% \mathrm{ET}_{\mathrm{m}}$, $\mathrm{Y}_{\mathrm{a}}=83 \% \mathrm{Y}_{\mathrm{m}}$, when $\mathrm{ET}_{\mathrm{a}}=80 \% \mathrm{ET}_{\mathrm{m}}, \mathrm{Y}_{\mathrm{a}}=95 \% \mathrm{Y}_{\mathrm{m}}$, when $\mathrm{ET}_{\mathrm{a}}=100 \% \mathrm{ET}_{\mathrm{m}}, \mathrm{Y}_{\mathrm{a}}=100 \% \mathrm{Y}_{\mathrm{m}}$.

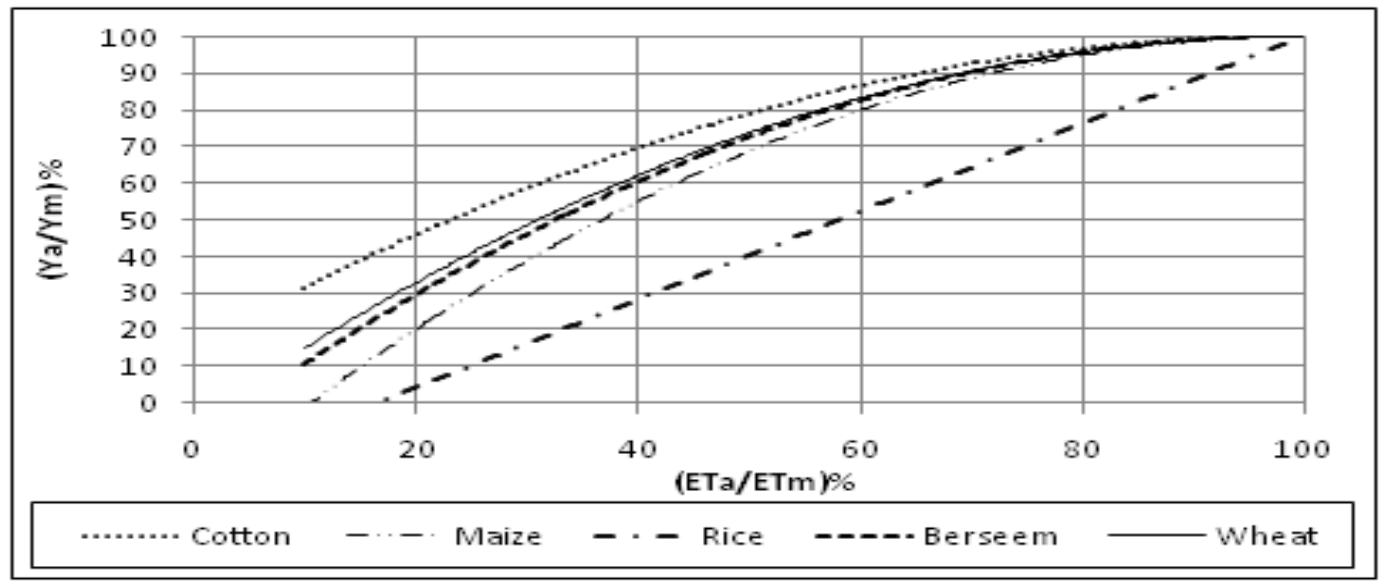

Fig.3 Relation between Relative Irrigation Depths and Relative Crop Yield

b-The relation between gross margin $(\mathrm{Gm})$ and irrigation water depth for the different crops with different water requirements and for cubic meter of irrigation water is shown in Fig.4. It results that, the maximum revenue is coming from maize crop and the minimum revenue is coming from wheat crop. The maximum water requirements is coming from rice crop and the minimum water requirements is coming from berseem crop.

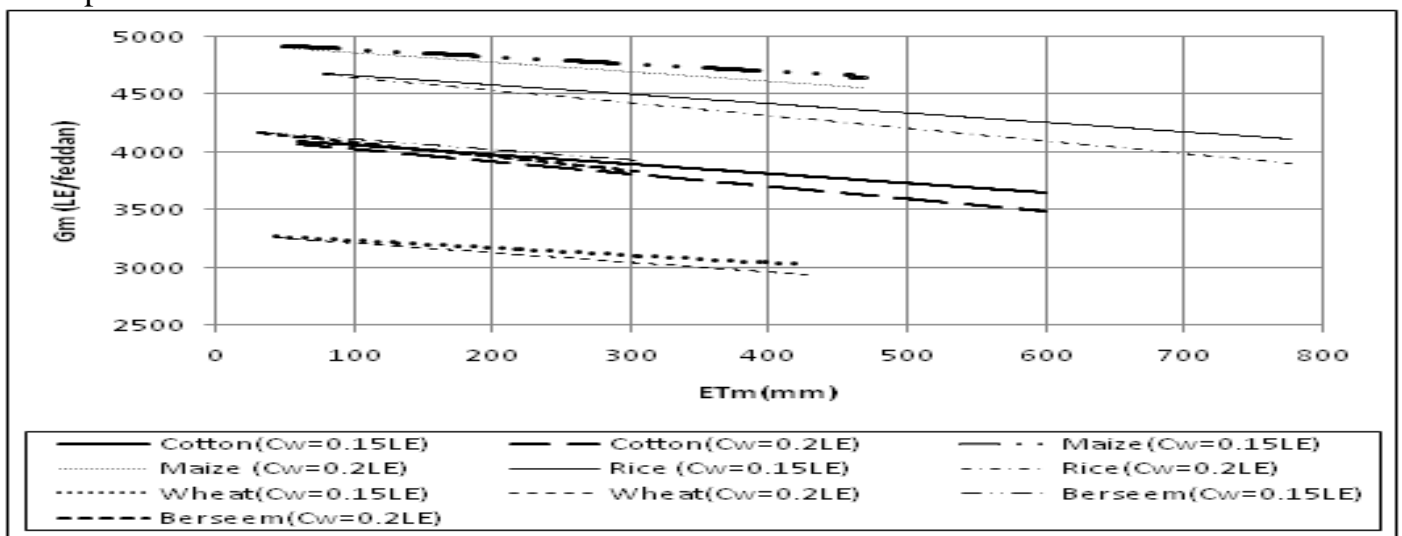

Fig.4 Relation between the Irrigation Depths and the Gross Margin for Different Crops for Different Water Cost 
c- A lower price of water charged to irrigator's increases farm income and increases the value of infrastructure investments. Lower water prices also increase the economic incentive for farmers to produce high water using crops. Low water prices discourage farmers from growing water saving crops. Finally, lower water prices encourage greater water use and encourage farmers to substitute water for other resources, such as land, labor, capital, and water-conserving technology.

d- An evaluation of your irrigation system will provide the necessary information for scientific irrigation scheduling. It will also tell you if there are experiencing excessive application losses (that is, runoff, deep percolation, wind drift) or if irrigation system needs service or improvement to increase application uniformity. The end result is water savings. Stated in a slightly different context, evaluating and improving irrigation system will help to stretch available water. Operate irrigation systems near their design limits to achieve peak efficiencies and uniformities.

\subsubsection{Model II:}

The results of this model are disseminated to technicians and farmers. This information is generated after two or three field campaigns in the study area when the production systems are sufficiently known. The results of this process are regarded as orientate, and an additional source of information for farmer decisions on planning his crops due to the uncertainly of the process and variability in farm costs.

Farm Returns, finally, improvements in irrigation water management can help maintain the long-term viability of the irrigated agricultural sector. Water savings at the farm level can help offset the effect of rising water costs and restricted water supplies on producer income. Improved water management may also reduce expenditures for energy, chemicals, and labor inputs, while enhancing revenues through higher crop yields and improved crop quality.

\subsection{The results of salinity:}

The different suggested alternatives of irrigation applications affect on crop yield as following:

1- For drainage water, the yield of all crops is full in the first alternative, the yield of wheat crop decreases by $2.5 \%$ in the second alternative, $9.81 \%$ in third alternative, $17.13 \%$ in fourth alternative, $24.45 \%$ in fifth alternative and $31.76 \%$ in sixth alternative. The yield of long berseem crop is full in the second and third alternatives, and decrease by $5.19 \%$ in fourth alternative, $12.5 \%$ in fifth alternative and $19.82 \%$ in sixth alternative. The yield of short berseem crop is full in the second and third alternatives, and decreases by $2.96 \%$ in fourth alternative, $10.28 \%$ in fifth alternative and $17.6 \%$ in sixth alternative. The yield of rice crop is full in the second and third alternatives, and decreases by $0.4 \%$ in the fourth alternative, $7.71 \%$ in fifth alternative, and $15.03 \%$ in sixth alternative. The yield of maize crop is full in the second and third and fourth alternatives, and decreases by $6.16 \%$ in fifth alternative and $13.48 \%$ in sixth alternative.

2- For sewage water, the yield of all crops is full in the first alternative, the yield of wheat crop decreases by $17.11 \%$ in the second alternative, $39.05 \%$ in third alternative, $60.98 \%$ in fourth alternative, $82.92 \%$ in fifth alternative and the crop is damaged in sixth alternative. The yield of long berseem crop decreases by $5.17 \%$ in second alternative, $27.11 \%$ in third alternative, $49.04 \%$ in fourth alternative, $70.97 \%$ in fifth alternative and $92.91 \%$ in sixth alternative. The yield of short berseem crop decreases by $2.95 \%$ in the second alternative, $24.88 \%$ in third alternative, $46.82 \%$ in fourth alternative, $68.75 \%$ in fifth alternative and $90.68 \%$ in sixth alternative. The yield of rice crop decreases by $0.38 \%$ in the second alternative, $22.31 \%$ in third alternative, $46.82 \%$ in fourth alternative, $68.75 \%$ in fifth alternative and $88.11 \%$ in sixth alternative. The yield of maize crop is full in the second alternative, $20.67 \%$ in third alternative, $42.7 \%$ in fourth alternative, $64.63 \%$ in fifth alternative and $86.56 \%$ in sixth alternative.

It results that the effect of mixing of fresh and drainage water is small on crops yield, but the effect of mixing of fresh and sewage water is big on crops yield, however sewage water damage the crops. Tolerance of crops to salinity varies between crops, long berseem, short berseem, rice and maize have tolerance to salinity greater than wheat crop. With an $\mathrm{EC}_{\mathrm{e}} \leq 5 \mathrm{mmhos} / \mathrm{cm}$ this level would not affect on crops yield, $\mathrm{EC}_{\mathrm{e}}>25$ mmhos/cm, wheat crop would not grow. Others crops yield would be reduced to about $90 \%$ of their potential yields. The effect of soil salinity on relative yield due to drainage water and sewage water which mixes with fresh water according to different alternatives as is shown in Fig. 5. 


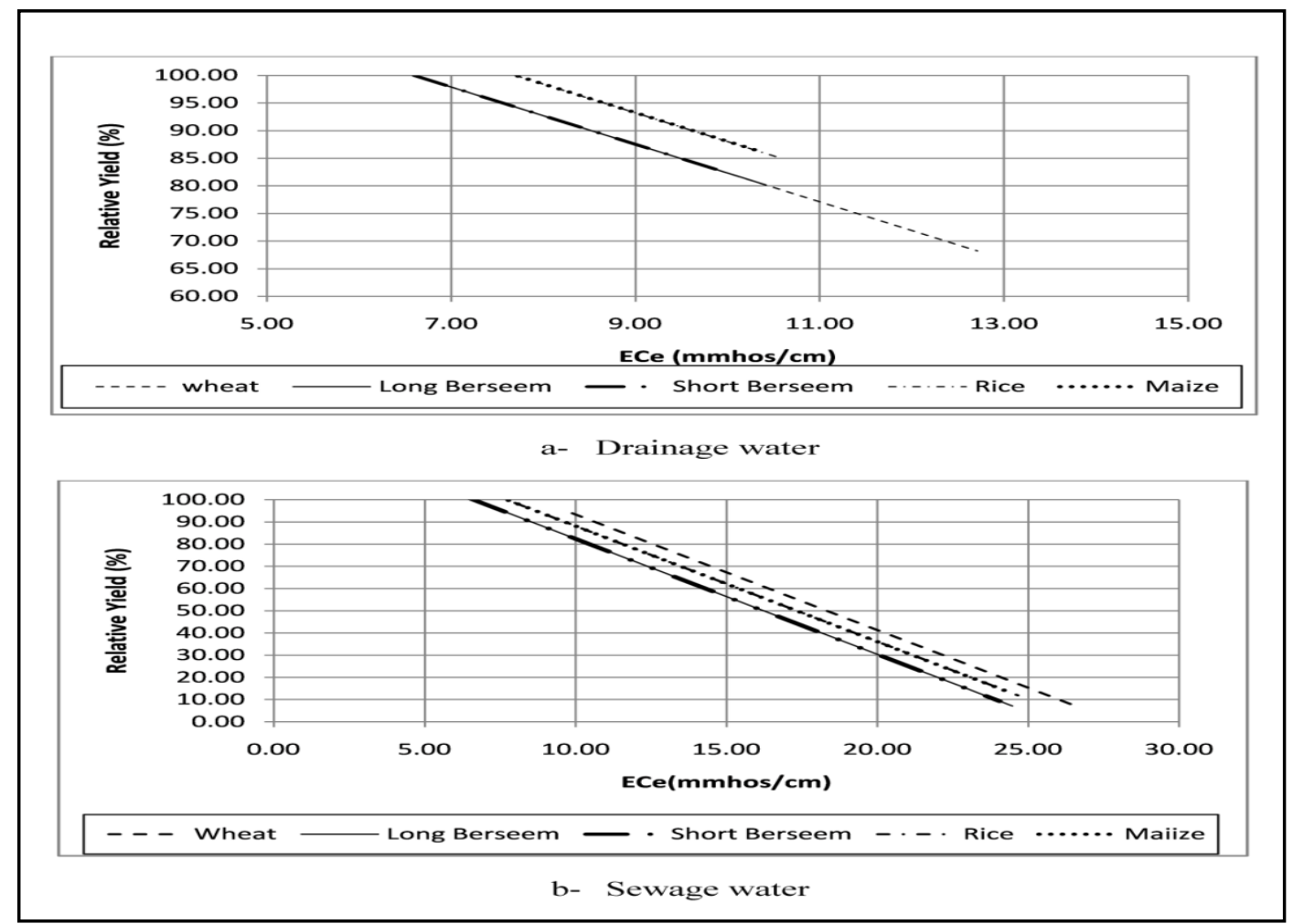

Fig.5 Effect of Salinity of Soil on Relative Yield

The solution to salinity management in the field is through leaching accumulated salts below the root zone. The relation between salinity of water $\left(\mathrm{EC}_{\mathrm{w}}\right)$ and leaching requirements for different crops due to drainage water and sewage water is shown in Fig. 6.

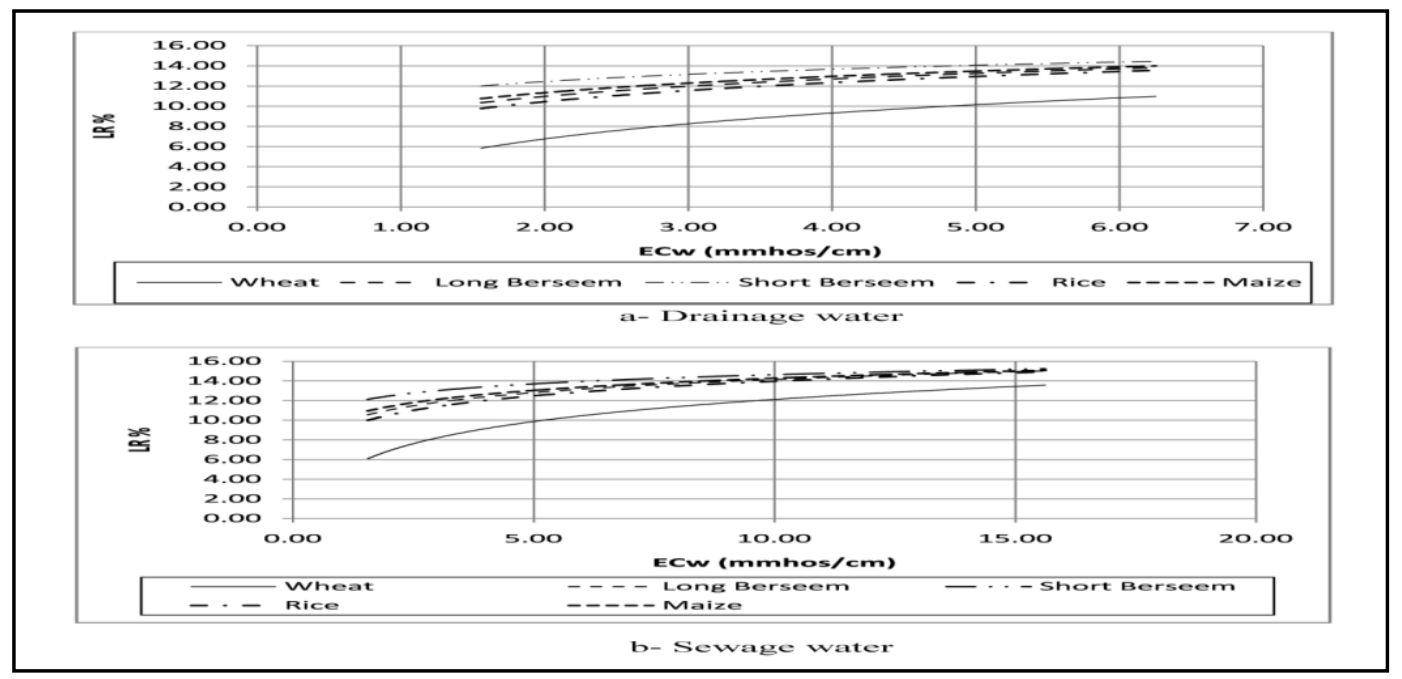

Fig.6 Relation between $\mathrm{Ec}_{\mathrm{w}}$ and LR for Different Crops

\section{Summary and Conclusions}

Water management is an important element of irrigated crop production. Efficient irrigation systems and water management practices can help maintain farm profitability in an area of limited, higher-cost water supplies. Efficient water management may also reduce the impact of irrigated production on offsite water quantity and quality. In this paper two stages of water irrigation management are studied, the first stage is irrigation scheduling; the second stage is effect of saline water. In the first stage performance of irrigation water management is assessed using two models for irrigation schedule by calculating eapo-transpiration and studying the effect of relative evapo-transpiration on relative yield of crop and the effect of depth of water irrigation on the net revenue. As a result of the water irrigation schedule, it would be advisable to improve the management and to recommend the farmer to follow more technical irrigation scheduling criteria. In the second stage the 
effect of saline water in crop production is studied by mixing supply of saline drainage water (4.6 - 7.8 mmhos $/ \mathrm{cm})$, moderately sewage water $(7.8-23.44 \mathrm{mmhos} / \mathrm{cm})$, and fresh water $(1.56 \mathrm{mmhos} / \mathrm{cm})$ in six ratios applied on crops yield which cultivated in Delta of Egypt. Moreover yield is high in alternate practice only with fresh water, whereas moderate saline irrigation waters in mixed practice gave the highest values of yield and growth. There was a strong negative relationship between crop yield and seasonal average of electrical conductivity of the soil solution. Increased soil and water salinity resulting from extensive irrigation practices have already diminished opportunities to develop the crop production system.

\section{References}

[1] Burton, Kivumbi, and El-Askari "Opportunities and constraints to improving irrigation water management: Foci for research" AGR WATER MANAGEA 1999; 40:37-44

[2] Leenhardt, Trouvat, Gonzalès, Pérarnaud, Prats, and Bergez "Estimating irrigation demand for water management on a regional scale I. ADEAUMIS, a simulation platform based on bio-decisional modeling and spatial information" AGR WATER MANAGEA 2004; 68:207-232

[3] Leenhardt, Trouvat, Gonzalès, Pérarnaud, Prats, and Bergez, "Estimating irrigation demand for water management on a regional scale II. Validation of ADEAUMIS" AGR WATER MANAGEA 2004; 68:233-250

[4] Ortega, Juan, and Tarjuelo, "Improving water management: The irrigation advisory service of Castilla-La Mancha (Spain)" AGR WATER MANAGEA 2005; 77:37-58

[5] Abdel Gawad, Arslan, Gaihbe, and Kadouri "The effects of saline irrigation water management and salt tolerant tomato varieties on sustainable production of tomato in Syria (1999-2002)" AGR WATER MANAGEA 2005; 78:39-53

[6] Malash, Flowers, and Ragab "Effect of irrigation systems and water management practices using saline and non-saline water on tomato production" AGR WATER MANAGEA 2005; 78: 25-38

[7] Ould, Yamamoto, Rasiah, Inoue, and Anyoji, "The impact of saline water irrigation management options in a dune sand on available soil water and its salinity" AGR WATER MANAGEA 2007; 88:63-72

[8] Melissa B. Haley, Michael D. Dukes, P.E., and Grady L. Miller "Residential Irrigation Water Use in Central Florida" J Irrig Drain E-ASCE 2007;

[9] Kuscu H., Bölüktepe F., and Demir A. "Performance assessment for irrigation water management: A case study in the Karacabey irrigation scheme in Turkey" AFR J AGR REC 2009; 4 (2): 124-132 Available online at http://www.academicjournals.org/AJAR

[10] FRANK A. WARD" Financing Irrigation Water Management and Infrastructure: A Review" Water Resources Development 2010; 26(3): 321-349

[11] Felix B Reinders "Irrigation methods for efficient water application: 40 years of South African research excellence" Water Research Commission 40-Year Celebration Conference 2011

[12] Staff Report "Agricultural Water Use in California: A 2011 Update" The Center for Irrigation Technology California State University, Fresno 2011

[13] Skhiri A., and Dechmi F., "Impact of sprinkler irrigation management on the Del Reguero River (Spain), I: Water balance and irrigation performance" AGR WATER MANAGEA 2012; 103:120-129

[14] Fátima Moreno-Pérez, and José Roldán-Ca nas "Assessment of irrigation water management in the Genil-Cabra (Córdoba, Spain) irrigation district using irrigation indicators" AGR WATER MANAGEA 2012; 09-21

[15] Kotba T.H, Watanabe T., Ogino Y., Tanji K. " Soil Salinization in the Nile Delta and related policy issues in Egypt" AGR WATER MANAGEA 2000; 43:239-261

[16] Natural Resources Management and Environment Department "Irrigation Water Management: Irrigation Water Need", FAO Corporate Document Repository, 2007; http://www.fao.org/nr/index_en.htm

[17] Liu W.Z, Hunsaker D.J, Li Y.S, Xie X.Q and Wall G.W "Interrelations of yield, evapo-transpiration, and water use efficiency from marginal analysis of water production functions" AGR WATER MANAGEA, 2002; 56: 143-151 